\title{
THE FALLACY OF CONTINUITY, ON THE REFERENCES TO ARISTOTLE IN ARENDT AND AGAMBEN ${ }^{1}$
}

\author{
LIESBETH HUPPES-CLUYSENAER ${ }^{2}$ \\ (University of Amsterdam / Netherlands)
}

\begin{abstract}
Agamben characterizes in Homo Sacer the modern state in terms of biopolitics, referring to the theories of Arendt and Foucault. Agamben takes up in this context on a very influential interpretation of Aristotle by Arendt. Arendt maintains in this reference to Aristotle a false idea of continuity and ignores the fact that - as Foucault shows - at the end of the eighteenth century an inherent connection was established between a completely new type of rationality, governing and the state. There is therefore an ontological difference between the ancient and modern era and this has - as will be shown in this article - far reaching consequences for the key-concepts of Homo Sacer such as bare life, sovereignty and law. The recent development of globalization gives new relevance to this ontological difference, especially by undermining absolute state-sovereignty.
\end{abstract}

Keywords: Biopolitics. Bare life. Sovereignty. Law.

\section{Introduction: the fallacy of continuity}

Enlightenment did not develop smoothly from preceding worldviews. There has not been a slowly evolving growth of knowledge in which the medieval ideas were just an addition to the ideas of Antiquity. Enlightenment did not just add even more new ideas to this conglomerate of classical and medieval knowledge. On the contrary! There have been violent debates in which paradigms were rejected and replaced by new ones. The views of Aristotle have been paramount in these debates, mostly dressed up however within the concepts of worldviews, completely different from his own.

Thus, while Aristotle for example explicitly rejected the idea of a Creator, he was conceived by Aquinas within a Creationist view. While he explicitly rejected the idea of a natural language and deemed all language theoretical, he was opposed by Ockham within a linguistic framework. While he defended a pluralistic conception of truth and rejected the idea of certainty of knowledge, he is conceived from the Middle Ages on up till now in terms of unity of truth and the quest for certainty. ${ }^{3}$ 
When authors like Arendt or Agamben refer to Aristotle in the context of their exposition of contemporary problems and without a specific research interest in Aristotle this can only have a metaphorical or literary-historic meaning. These authors may adhere to these ideas of Antiquity to which they refer or they may oppose them. In both ways they commit the fallacy of continuity because they do not take into account the ontological assumptions of these references.

References to Aristotle in the exposition of contemporary problems can only have a scientific meaning when the author maintains that a re-opening of the debate on the ontological assumptions of Aristotle can be relevant for contemporary problems in the field. This is what I want to maintain in this article. In the first part I will explain the views of Arendt, Foucault and Agamben. In the second part I will treat the differences between the modern and ancient ontological assumptions.

\section{Part I: Arendt, Foucault and Agamben}

\section{I.1. References to Aristotle}

In the introduction of Homo Sacer Agamben ${ }^{4}$ states, referring to the first chapter of Aristotle's Politics, that in the classical world the simple natural life was excluded from the polis and was restricted - as a life that only reproduces itself - to the sphere of the oikos. Agamben refers also to the passage in which Aristotle states that human society differs from the way other living animals are grouping together because humans have speech, which makes it possible to indicate the advantageous and the harmful and therefore also the right and the wrong

\footnotetext{
for it is the special property of man in distinction from the other animals that he alone has perception of good and bad and right and wrong and the other moral qualities, and it is partnership in these things that makes a household and a city-state. ${ }^{5}$
}

By these two references to Aristotle Agamben follows an influential interpretation by Hannah Arendt in her book The Human Condition. Arendt distinguishes in this book between two meanings of the concept of "life": zoe in the sense of the purely biological process of dying and being born (called "the bare life" by Agamben) and bios in the sense of the events taking place during somebody's life which are seen by others and can be told and remembered in the ethic@-Florianópolis, v. 10, n. 2, p.223-253, Dez. 2011. 
form of a story. ${ }^{6}$ As a physical being (zoe) man belongs to a species, as a being which speaks and acts (bios) he is unique. ${ }^{7}$ People can experience this uniqueness however only in the eyes of others. ${ }^{8}$ It is by acting and speaking that people reveal this unique personal identity. The true place of politics lies therefore, according to Arendt, "between people living together for this purpose, no matter where they happen to be". 9

\section{I.2. Arendt's Human Condition}

Arendt distinguishes in her book between four types of human activity: labour (the slave), work (the craftsman), action (the citizen) and thinking (the philosopher), of which the first three form together the most elementary articulation of the human condition. She explicitly does not pay attention to the activity of thinking in this book as only few men are capable of this. ${ }^{10}$ I will first explain how Arendt defines these types of activity and then how she formulates her theory on biopolitics in these terms.

Labour - To answer the necessities of life the head of the household had to be a despotic ruler who treated the members as slaves. This enslavement is specific for labour and this is why the Greeks held labour in contempt. The rise of the city-state meant that the head of the household received besides his private life a second life: his bios politicos as a citizen. Every citizen belonged thus to two orders of existence - the private (oikos) and the public (polis). ${ }^{11}$

Work - Unlike the products of labour which are the outcome of a "rhythmically ordered performance", the products of work contribute according to Arendt to the thing-character of the world. This means that they create a world which is not objective, but man-made. The products have a reality of their own. They can be destroyed, in which case they no longer give meaning to the world. ${ }^{12}$

Action - The meaning of action is intangible and depends for its reality "on the" transformation "of the intangible into the tangibility of things". ${ }^{33}$ This materialization will suffocate however its true nature, because the product which is thus made, will always get mixed up with need (labour) and utility (work). Arendt distinguishes between the social world which consists of these products and the political world in which the meaning in pure form is 
expressed. ${ }^{14}$ "Therefore whoever consciously aims at being 'essential', at leaving behind a story and an identity which will win 'immortal fame', must not only risk his life but expressly choose, as Achilles did, a short life and premature death." ${ }^{15}$ Courage is for the Greeks the political virtue par excellence. Arendt's theory on biopolitics focuses on the "loss of action", on the loss of this "agonal conception of politics".

The Greeks saw legislation primarily as a pre-political activity, like making the rules of a game. ${ }^{16}$ Plato and Aristotle were - according to Arendt - the first who treated politics as work instead of action, seeing legislating and the execution of decisions by vote as the most legitimate political activities. The reason to do so is their wish for a stable order in which the risk and dangers of "action" are eliminated. ${ }^{17}$ Politics degenerated thus according to Arendt already at that time.

Specific for the modern age is in the eyes of Arendt the rise of the social world, which is neither private nor public. Society is perceived in modern times as a super-human family or household. Its political form is the nation. This social world originated in her opinion from the Christian reversal of the "agonal" expression of personal uniqueness towards the celebration of the sacredness of life. This is also how Agamben situates "the origin of biopolitics" referring to Arendt. In Modern times there was according to Arendt a second reversal in which "action" - in its new Christian connotation - became more important than contemplation. The scientific thought that corresponded to this rise of the social world was the national economy. By this modern development freedom is no longer - as for the Greeks - exclusively located in the political realm, but in the social realm, while force or violence becomes the monopoly of governments. These governments are involved in a gigantic nation-wide administration of housekeeping. When this type of government turns into a democratic rule it is in a certain sense a "nobody" who rules, but this does not take away the risk of a totalitarian character of such a rule. $^{18}$

It is decisive that society on all its levels excludes the possibility of action, which formerly was excluded from the household. Instead, society expects from each of its members a certain kind of behaviour, imposing innumerable and various rules, all of which tend to 'normalize' its members, to make them behave, to exclude spontaneous action or outstanding achievement. ${ }^{19}$ 


\section{I.3. Conclusions on Arendt}

Arendt focuses in her book on "action". The focus on "action" in the sense of "courage" as a key-concept of the Greek moral and political culture which has lost its meaning in the modern world will be just my own contend. This is why it is important to reflect critically on her views. I will explain in part II of this article how she saves in her exposition of the meaning of "action" three ontological notions and how she disarms her critique of the modern world by this. These assumptions are:

- By understanding the distinction between oikos and polis as an exclusion of slaves and women from the polis, Arendt refers to the ideas of the natural equality of men and the absolute state, introduced by the Spanish naturalists in explicit opposition to the view of Aristotle.

- By the distinction between zoe and bios Arendt refers to a disenchanted concept of physical nature, introduced by Descartes in explicit opposition to the view of Aristotle.

- The degeneration of politics from action into work refers to a modern positivist concept of law, which is explicitly rejected by Aristotle. ${ }^{20}$

\section{I.4. Foucault's essay on the "Political Technology of Individuals" 21}

According to Foucault the main question to be asked is how we have been led to recognize ourselves as a society, as a part of a social entity, like the nation or the state.

Political technology starts according to Foucault at the end of the eighteenth century when the first systematic program of public health was published ${ }^{22}$ while at the same time the French Revolution gave the signal for the great national wars of our days with their huge mass slaughters. The fact that the care for individual life became a duty for the state (biopolitics) is thus somehow connected with the extreme endangerment of that same life. For Foucault this phenomenon is related to the specific form of rationality which developed in the seventeenth and 
eighteenth century. This rationality is directly related with a specific conception of the state and with a new kind of governing indicated by the concept of "policy".

The new concept of the state was according to Foucault a break with the Christian as well as the Machiavellian tradition. The Christian tradition claimed that government had to respect a whole system of human, natural and divine laws. The Machiavellian tradition focused on the reinforcement of the link between prince and state, the state being nothing else than acquired territory which had to be held against internal and external rivals. In the new conception the state has an independent existence as a kind of natural object with its own nature and rationality. According to Foucault it is in the seventeenth and eighteenth century for the first time that to govern a state means to be a politician and to have a specific political competence and knowledge. The kernel of this political competence is statistical knowledge about social mechanisms. $^{23}$

Good governance is thus not conceived any more as the achievement of an equilibrium between several centers of power but as the policy to control the social mechanisms in order to reinforce the strength of the state for its permanent struggle with other states. From the perspective of the government the individual has only relevancy as far as he influences the strength of the state. Sometimes what the individual has "to do for the state is to live, to work, to produce, to consume; and sometimes what he has to do is to die". ${ }^{24}$

He concludes his essay with the remark that the failure of political theories in everyday political reality is due to the type of rationality in which these theories are rooted. There is a constant correlation between an increasing individualization and a reinforcement of the totality in which these individuals are integrated. This constant correlation is permitted by the antinomy between law and order. The modern political rationality has tried to conciliate this antinomy and this has resulted in the integration of law into the state's order. 


\section{I.5. Conclusions on Foucault}

Foucault maintains that although the political literature of the seventeenth century refers currently to Greek cities there is something quite different going on in the modern political theory. This is just my own contend.

\section{I.6. Agamben's Homo Sacer}

Agamben takes up on Arendt's reference to Aristotle and her view, that the modern state has caused the degeneration of politics by making the care for the bare life its central focus. Agamben calls this biopolitics, referring to Foucault's La volonté de savoir (1976). He points out that Arendt unlike Foucault did not see the systematic connection between biopolitics and the destruction of human life, ${ }^{25}$ while Foucault did not - like Arendt - make references to the concentration camps or the great totalitarian states of the twentieth century. This way neither of them acknowledged the fact that biopolitics has become a real threat to humanity as such. ${ }^{26}$

Agamben thinks that the acknowledgement of this threat asks for an analysis of the connection between biopolitics and political power. He doesn't agree with Foucault's view on power. Foucault made a sharp distinction between the old type of sovereign power which was located in the person of the king and the new power constituted by the technical knowledge of social mechanisms. In Foucault's opinion this new power could no longer be perceived in the old institutional juridical frames. It rested on the general acceptance of the knowledge of how social mechanisms influence people and steer them in a certain direction. Therefore, according to Foucault, power had to be studied as a pervasive technique brought about as knowledge by a specific form of rationality.

Agamben's starting point for a new analysis of power is the way Foucault describes at the end of his essay the constant correlation of individualization and reinforcement of totalitarian structures. Agamben concludes that Foucault's early death has prevented him from looking for the point at which the techniques of individualization and totalizing procedures converge. In order to find this point he analyses the constitutive principles of political order. 
To Agamben the institution of a political order and its regular re-installment is not a religious but a political phenomenon. Not the Gods in a time far away, but an actual sovereign decides on the normal order of law. He legitimates his decisions by the laws of this normal order while at the same time he is the one who has the legal right to decide that there is a situation at hand of war or treason and that measures have to be taken which put aside the normal legal order. As the sovereign has the legal right to decide this at any moment, the sovereign is at the same time within the legal order and outside it, holding it in suspense. ${ }^{27}$

The sacredness Agamben studies in Homo Sacer is not of the religious type, which is studied by anthropologists, but a specific juridical/political device. The ambiguous legal status of the Homo Sacer is according to the research of Agamben the intended result of a sovereign decision to affirm by law a zone of indistinction: ${ }^{28}$ a sphere in which neither human law nor religious law is applicable. In this sphere - a legally affirmed state of exception - anything can be done, legitimated by law, without the risk of either human or divine penalty.

Agamben shows that the figure of Homo Sacer was as a legal phenomenon already existent in Roman Law. The decision by which somebody is declared a Homo Sacer means that he is declared to be somebody who is excluded from divine law as well as from human law. Normally to be excluded from human law would mean to be sacred and thereby untouchable and above law. But the Homo Sacer is somebody who people are allowed by law to kill without committing homicide. Such a decision will be taken when a political crime, like treason, is at stake. In such a case a normal trial seems inappropriate. ${ }^{29}$ Anyone may kill such a traitor without committing homicide. By contesting the reign of the king who is himself excluded from law, the traitor acquires also in a way a status outside the normal order. The situation of treason is a situation in which the reign of the king, the normal order, is at suspense, it creates a zone of indistinction. It is the sovereign however who decides that there is a situation of treason at hand. This power to decide upon the exception is the pure mark of sovereignty.

Agamben explains that biopolitics has created a situation in which the exception has become the rule and in which the bare life has become the Homo Sacer. The root of this state of affairs has to be found, according to Agamben, in the Greek notion of politics. Politics appears to him as the truly fundamental structure of Western metaphysic. Man is according to this metaphysics the only creature that can talk and think. Via politics man uses his language to 
separate and oppose himself to his own bare life. This is why people can only experience themselves in the political realm as thinking and talking human beings by keeping the bare life at a distance. By doing so however, they have politicized the bare life as the sole phenomenon which can mirror their true essence. They have by implication included what they wanted to exclude. $^{30}$

\begin{abstract}
(...) The Foucauldian thesis will then have to be corrected or, at least completed, in the sense that what characterizes modern politics is not so much the inclusion of zoe in the polis - which is, in itself, absolutely ancient - nor simply the fact that life as such becomes a principal object of the projections and calculations of State power. Instead the decisive fact is that, together with the process by which the exception everywhere becomes the rule, the realm of bare life - which is originally situated at the margins of the political order - gradually begins to coincide with the political realm, and exclusion and inclusion, outside and inside, bios and zoe, right and fact, enter into a zone of irreducible indistinction. ${ }^{31}$
\end{abstract}

Decisive for the situation in which the exception has become the rule is, according to Agamben, the fact that the democratic rule has made every human being at the same time a sovereign and an object of sovereignty. This is the condition which seems to guarantee the voluntary servitude of individuals. The mark of sovereignty is however the decision to make the life of somebody into a life that can be taken without committing homicide. This is the secret tie between power and bare life. This is also why it is impossible to place the bare life at a distance of politics, why it is always included in it. In the modern democratic state this hidden structure comes into full light in the form of biopolitics. Every human being is at the same time a sovereign, placed above human and divine law, who may wish to create the freedom and happiness of all, and a subject who has to accept the decisions of others who as a sovereign may place his bare life in the situation of the Homo Sacer. ${ }^{32}$ The wish to be essentially human incites in every individual the constant wish for the mark of sovereignty and this means to hold the lives of other individuals in suspense. ${ }^{33}$

\title{
I.7. Conclusions on Agamben
}

For anthropologists the courageous Achilles of Arendt and the Homo Sacer of Agamben are the same symbolic figures. For them a Homo Sacer is a man possessed by a vague power which can act for good and for evil. This power spreads through all kinds of things and beings, 
plants, animals and humans alike. In a man it shows in his physical force or any other eminence or excellence which he possesses. Anthropologists find these beliefs in many "primitive" cultures like in Melanesia where this power is called Mana, and with the Indians who speak of Wakan. ${ }^{34}$ Although Agamben refers extensively to Arendt he does not treat this connection and does not criticize the way Arendt modernizes this "primitive" concept into the wish for the immortality of a personal uniqueness.

At the end of the nineteenth century the new social sciences study religion because of its relevance for the constitution of society. Religion creates by interdicts a distinction between the sacred and the profane. The social function of interdicts is not that the behavior is in itself disagreeable or dangerous, but that these interdicts create the social solidarity in a group by which individuals belong to a society. As Durkheim formulates it: "Religious force is only the sentiment inspired by the group in its members, but projected outside of the consciousnesses that experience them, and objectified". ${ }^{35}$ Although Agamben refers extensively to Foucault he does not treat the question if Foucault uses the image of God as the great governor of the world who sees and hears everything when he sketches the modern disciplinary society in the context of a panopticum. Could a disciplinary society survive without such a projection ${ }^{36}$

The normal order of good and bad has to be reinstalled regularly. This "re-installment" will have a purely symbolic, religious form according to anthropologists. Durkheim calls penal law religious law and restricts this type of law to those acts (religious crimes) that offend strong and definite states of the collective conscience. ${ }^{37}$ In the ceremonies which are used when calamities endanger the group life anthropologists had been confronted in their research with an ambiguity of the notion of sacredness, as sacred things seemed to represent something evil and good alternatively. It is in respect of this discovery of the sacred man as an ambivalent symbolic figure that Agamben refers to the work of anthropologists. He criticizes it as a psychologization of religious experience. ${ }^{38} \mathrm{He}$ ignores this way the question of how group solidarity can develop in communities where central authority is lacking or uncertain and unstable. Durkheim describes how absolute sovereignty can stimulate forms of violent expiation which resemble the religious forms and which can develop at any moment in any kind of society where an absolute sovereign had seized power. ${ }^{39}$ It is in this context of absolute sovereignty that Agamben uses the figure of Homo Sacer. This means that he has to restrict his claim about the truly fundamental structure of 
Western metaphysic. It only pertains to the deductive conception of natural law of the Spanish naturalists.

Agamben explains very well how modern culture can be focused on safety and solidarity while it is at the same time obsessed with violence and competition. His theses about law and society however do not convince. When every citizen is sovereign and at the same time object of sovereignty it seems likely that the result is that nobody easily obeys the rules and that it is very difficult to organize power. That the exception becomes the rule means in this case that sovereignty is threatened constantly by people resisting to just follow the rules, making their own interpretations or even refusing to find out what the law precisely demands. This is a situation which seems at a far distance from the concentration camp that Agamben takes to be the paradigm of contemporary politics. ${ }^{40}$

\section{Part II: Modern and Aristotelian Ontology}

Enlightenment has brought a new rationality inherently connected with a new way of governing, both rooted in an absolute conception of state sovereignty. As the globalization undermines the nation state it has become necessary to rethink the ontological assumptions of Enlightenment and to re-interpret the old discussions.

\section{II.1. New rationality and its connection with absolute state sovereignty: the birth of biopolitics}

Mostly Kant's formulation of a Copernican Turn is indicated as the decisive change between pre-modern and modern thought. Much more telling is however the formulation of this same turn in a preceding passage in the same preface to the second edition of Kritik der reinen Vernunft, which I want to cite in full length:

\footnotetext{
When Gallilei experimented with balls of a definite weight on the inclined plane, when Torricelli caused the air to sustain a weight which he had calculated beforehand to be equal to that of a definite column of water, or when Stahl, at a later period, converted metals into lime, and reconverted lime into metal, by the addition and subtraction of certain elements; ${ }^{*}{ }^{41}$ a light broke upon all natural philosophers. They learned that reason only perceives that which it produces after its own design; that it must not be content to
} 


\begin{abstract}
follow, as it were, in the leading-strings of nature, but must proceed in advance with principles of judgement according to unvarying laws, and compel nature to reply its questions. For accidental observations, made according to no preconceived plan, cannot be united under a necessary law. But it is this that reason seeks for and requires. It is only the principles of reason which can give to concordant phenomena the validity of laws, and it is only when experiment is directed by these rational principles that it can have any real utility. Reason must approach nature with the view, indeed, of receiving information from it, not, however, in the character of a pupil, who listens to all that his master chooses to tell him, but in that of a judge, who compels the witnesses to reply to those questions which he himself thinks fit to propose. To this single idea must the revolution be ascribed, by which, after groping in the dark for so many centuries, natural science was at length conducted into the path of certain progress. ${ }^{42}$
\end{abstract}

The basic question to ask about the quotation of Kant is: "Reason acts, but which reason, whose reason?" And indeed, the key-assumption of this new type of rationality is the belief in a sovereign people (we, a nation, a people) which can be the bearer of a uniform interest, the fulfilment of which enhances objective truth. This is the inherent relation between the new type of rationality and absolute sovereignty; it is how science involves politics and creates an inherent relation between science and governing.

Aristotle has discussed the relation between theoretical science and the practical science of politics in the Nicomachean Ethics and has rejected a fusion. To study nature from the perspective of human interest is politics. What is wholesome or good for human beings is however different from what it is for fish. Therefore it would only make sense for politics and science to fuse when man would be the highest being in the world, which he is not according to Aristotle and which he is according to the Bible. It is therefore evident for Aristotle that wisdom cannot be the same as political science, while the new type of rationality is promoted by the biblical view that God made nature to serve man. ${ }^{43}$

Kant contributed at the end of the eighteenth century to a development which had started already long before. Until his contribution the practical problem had been how to establish certainty about the kind of knowledge, which scientists like Gallilei and Kepler obtained by mathematical a priori reasoning. The secondary qualities, which are perceived, are variable and could therefore not be used to assemble knowledge about the permanent non-perceivable characteristics of matter. By his method to ask questions Kant introduced a criterion for selection through which one could determine how much variation in the perceivable secondary qualities could be accepted as "the same", because within that range the same results could be produced over and over again. 
The inherent practical value of modern science for governing is therefore to harmonize, equalize and unify, in other words to get rid of differences. This harmonization presupposes a centralized state power which represents the common interest and prompts the questions. It presupposes this way the equality it will realize by governing. I will first elaborate the difference between the old and the new type of governing and then further explore the assumptions of biopolitics.

\section{II.2. Difference between the ancient and modern conception of governing}

According to Foucault it is in the seventeenth and eighteenth century for the first time that to govern a state means to have statistical knowledge about social mechanisms. ${ }^{44}$ A comparison between the conception of politics of Durkheim and Aristotle can explain this difference between ancient and modern times.

In many ways there is a resemblance between the ancient view on the state of Aristotle and the modern view of Durkheim. For both of them the state arises from facts, from an actual development which can be described empirically. ${ }^{45}$ Both maintain that there are states in different stages of development, some still very primitive others much more developed. Both describe the primitive form as being based on kinship, as having a clan structure, as having an authority structure based on this clan-structure and as having a religious character. ${ }^{46}$ Aristotle calls the primitive form a household and the developed form a city. Durkheim calls the primitive form mechanical and the developed form organic. Both describe the developed form as not just more numerous, but as different in kind. ${ }^{47}$ Aristotle describes the difference in type as a distinction between the authority of a master over slaves and the authority of a magistrate in a republic. The more advanced a society is, the more the relations will be republican which means relations between free and independent persons. To be a master is not a high office like that of a magistrate. "The master must know how to direct the tasks which the slave must know how to execute. Therefore all people rich enough to be able to avoid personal trouble have a steward who takes this office, while they themselves engage in politics or philosophy." 48 The relation of the man to his wife and children is in barbarian tribes the same as the relation with the slave, while in a more advanced society these relations in the household have more political traits. ${ }^{49}$ Durkheim 
describes the difference in type as a change from a strict communal and religious morality into a society with individual differentiation. ${ }^{50}$

According to both the developed form of the state has an authority structure with official services common to all and is less repressive as its core is a relation based on mutuality. ${ }^{51}$ Both understand the developed form as a body like the human body, of which the individual is an integral part. Just like a hand cannot exist alone, also an individual cannot exist alone. This is why Aristotle calls man a political animal and the city prior in nature: there is in every man a natural impulse to form a political partnership. ${ }^{52}$ Finally both maintain that law "has no power to compel obedience besides the force of custom". 53

There is however a very great difference between Durkheim and Aristotle which has to do with their different conception of a natural order and as a consequence their different conception of law. Both maintain that law has no power to compel obedience besides the force of custom. For Durkheim, like for all social scientists, these customs are routines with a certain moral significance. The regularity in behaviour can be observed empirically just like the movements of other physical phenomena. This leads to statistical knowledge which is explained by social mechanisms.

It is not easy to explain Aristotle's conception of law and custom, but it is certainly something quite different from a routine. Although Aristotle acknowledges the fact that there are patterns in nature - forms: formative principles - he is at the same time impressed by the infinite variety of circumstances and situations. ${ }^{54}$ Although in theory realistic scientific knowledge of the patterns can be derived via abstraction from a lot of experiences, this knowledge can in practice only be a rough understanding. ${ }^{55}$ He explains the structure of unity and differences in nature by the assumption that the formative principles are induced into matter in a certain specific gradation and that every organism - relative to the complexity of its nature - has a kind of intelligence by which it can adapt its own specific variation to the specific variability of its environment. ${ }^{56}$ The driving force of this intelligence is the search for well-functioning, for happiness. ${ }^{57}$ By these learning processes the organisms develop a certain individual character, which expresses itself in their actions.

To learn is not an easy job and there is a big difference between practical learning and theoretical learning, ${ }^{58}$ between action intelligence and speech intelligence. As the variability is 
extreme it is not possible to understand the nature of things in a conceptual way other than by some intuition of its general type and some intuition of the merit of its individual differences. ${ }^{59}$ The pure practitioner leaves it at that. By not reflecting on his experiences he only knows how to do things, but he does not know why. By his speech man differs from animals. He is able to reflect. This reflection will in no way bring him sure knowledge. But it is like the botanist who by his - in a certain sense completely insufficient - attempts to categorize nature sees an enormous amount of differences in the phenomenon of grass, where somebody who never tried to categorize these phenomena only perceives very roughly something like "green stuff". Thus trying to catch experiences with words gives man a rough awareness of the general patterns in the world and at the same time a detailed vision of its extreme variability. Not the result of such a theoretical enterprise counts. There is no proof of certainty possible here, it is a speculative activity. It is the attitude that counts, the kind of attention and the broad experience which prevent narrow mindedness. The belief in certainty of knowledge would destroy the essence of this attitude.

Custom indicates the way people try to catch with words their idea of actual habituations which they perceive as natural and just.

For Durkheim society is a social order of routinely organised interactions between individuals. Similarity and difference are the formative principles of communal life. The bond which is created by similarity alone is weak: "The social molecules which can be coherent in this way can act together only in the measure that they have no actions of their own, as the molecules of inorganic bodies." ${ }^{60}$ Inorganic matter falls easily apart. ${ }^{61}$ Therefore the social bond in primitive societies has to be strengthened by severe penal laws, securing a common morality, which is religious and symbolic of nature.

The development into a more advanced type of society is brought about by a purely mechanical force. The more numerous a society is and the more dense the contacts are the more advanced the society becomes. In the advanced society the social bond is created by difference. Its solidarity is due to the division of labour between organs, which resembles the way organs cooperate in the human body. Each organ, in effect, has its special physiognomy, its autonomy. And, moreover, the unity of the organism is as great as the individuation of the parts is more marked. ${ }^{62}$ In this advanced type restitutive law (civil law and administrative law) is highly 
developed. There is an occupational morality for each profession. In the interior of the same group of workers there are usages and customs common to the same order of functionaries which no one of them can break without incurring the censure of the corporation. "We are thus led to consider the division of labour in a new light. In this instance, the economic services that it can render are picayune compared to the moral effect that it produces, and its true function is to create in two or more persons a feeling of solidarity". ${ }^{63}$ It is more than just exchange. It is a very deep state. "The image of the one who completes us becomes an integral and permanent part of our conscience." 64

For Durkheim, like for all modern authors, morality is not a characteristic of the individual, but of the communal life. It is the communal life which inspires the individuals with thoughts, values, conscience and language. Because of their generality these values and concepts inspire the individual to behave in a regular way. Politics becomes a kind of monitoring of these interrelated regularities. By accumulating scientific knowledge the cooperation can be made more accurate and predictable.

For Aristotle the purely individual intuition of what is asked for by natural law is also in politics decisive. The state is to him, just like to Durkheim, more than only a provision for exchange and solving conflicts. ${ }^{65}$ It has its own communal life and this communal life has a moral quality. But it is by individual actions and decisions that it gets this moral quality. Decisive is the way the individual magistrates solve the problems of their offices such as to ensure that the natural dependency of people with low intelligence on people with high intelligence is not misused but keeps its natural expediency and virtue; or that the acquisition of wealth in a state keeps its proper limits and does not turn into sheer greediness; or that the differences in property are counterbalanced by measures such as common meals, or that there are made provisions for education. ${ }^{66}$ This Ancient conception of politics is well captured by Gerard Drosterij with the term "Jurisdiction", which does not simply refer to the modern idea of the application of legislation, but much broader to the decisions and actions by magistrates to implement natural law. ${ }^{67}$ Not knowledge, but attitude is prerequisite to be a good magistrate for Aristotle. And this attitude is acquired by theoretical science combined with experience. 


\section{II.3. Mechanisation: the Birth of Bare Life}

Descartes has introduced the mechanical view on humanity, which was so obvious present in the work of Durkheim. His view was in direct conflict with the scholastic interpretation of Aristotle which was at that moment prevailing. Although Descartes was not persecuted in the Netherlands, it was forbidden to call his name in Utrecht University and two years later also in Leiden University. The conflict in Utrecht University started with a public disputation on the magnet of which Henricus Regius, a junior professor of medicine and botany, and correspondent of Descartes, denied that it had an occult, attractive quality. Important for the spread of the new ideas was a public disputation at 10 June 1640 in which Regius introduced the Cartesian theory of the circulation of blood. The final outburst however came on 8 December 1641, when Regius had put forward for discussion the thesis that "man is an accidental being", which is to say that man is not a single unity of mind and body. ${ }^{68}$

In December 1641 Gisbertus Voetius, professor of theology in Utrecht since 1636, published an essay On the Nature and Substantial Forms of Things which became famous as a general critique on the so-called New Philosophy of Anti-Aristotelians.

The description of this debate between the New and the Old Philosophy by Van Ruler can be summarized in the following way: In the old philosophy each type of plant and animal is said to belong to one of the unique species created in the beginning by God. ${ }^{69}$ Nature has a fixed, determinate end for every species to guide the process of growth. There is an inherent goaldirectedness in plants and animals to reach this end. ${ }^{70}$ This is its substantial form, its essence, its permanent nature. ${ }^{71}$ Every individual thing is a combination of such a substantial form and corporeal matter. The specific qualities of natural things by which they are perceived by humans are thought to be inherent in the things themselves and the efficient cause of their action.

In the new philosophy the diversity of animals and plants is explained by the fact that the differences between species originate from the mere disposition of corporeal matter according to motion, rest, position, shape and size of the parts, which alone were imparted to created things by God. ${ }^{72}$ Therefore all differences are accidental. Descartes argues that all physical theories that attribute to material things any analogy to mental considerations should be rejected: Lifeless things have no inclinations; these are the privilege of spiritual beings only. ${ }^{73}$ 
This means the rejection of the idea of substantial forms by the new philosophy. Sensible qualities have no existence outside the human awareness. They are reduced to the primary "mechanical" properties of insensible particles. ${ }^{74}$ As Descartes formulates it:

\begin{abstract}
And as we have already said that there is nothing, outside our thought, which is similar to the ideas that we perceive of tickling or pain, we may believe likewise, that there is nothing similar to that which we perceive of heat, but that everything which can variously stir the small parts of our body, may arouse this feeling in us. ${ }^{75}$
\end{abstract}

The animal body might, according to Descartes, well be compared to a machine made by a divine Hand. ${ }^{76}$ Without supposing anything but the presence of a certain heat, the mechanical principles suffice to explain the workings of the human body and supplant the Aristotelian principles of the vegetative and sensitive soul. ${ }^{77}$

The new philosophy thus stripped the physical world of its real sensible qualities. Instead of the idea of natural objects having individual centres of causal activity - powers of action "from within" - Descartes' philosophy came up with a different perspective: causality as an omnipresent pressure "from without" ${ }^{78}$ He believes that it is possible to describe the physical world in mechanical terms alone and explains the whole clockwork of Nature without introducing any other effective principle apart from God causing and maintaining movement in a determinate quantity of matter. There is only a single efficient cause for all natural mechanisms in Cartesian philosophy: God.

The only principles of motion which Descartes accepted for spiritual beings were their bodily movements (which are shared with animals) and their rational mind - their speechintelligence. The New Philosophy rejected the sensitive soul and the specific kind of intelligence which was accordingly ascribed by Aristotle to animals and human beings alike. This marks the "birth of bare life".

Speech is a collective and general phenomenon. As Wittgenstein formulated it: private language does not exist. The rejection of the sensitive soul means a rejection of the nonconceptual, intuitively grasped perceptions by individuals of the individually shaped context in which they have to act. By attributing to the human being only a body and a ratio, attributing to the ratio the task of the control of the body, the individual is forced into obedience to the generalized perception of the world that has won authority and is commonly accepted as rational. This is the birth of obedient bodies which can be disciplined by social science. 


\section{II.4. Action as a key-concept of the Greek moral and political culture}

It is now possible to correct Arendt's view on action as a key-concept of the Greek moral and political culture.

For Aristotle the action-intelligence shared with animals was the primary seat of morality. Barnes explains that Aristotle's view on morality is quite different from our present notion of moral philosophy, which refers to Kant or Mill. ${ }^{79}$ His explanation can be summarized in the following way. One might be inclined to think that for Aristotle a good shoemaker is good just insofar as he does well the things shoemakers professionally do, that he is an expert in the technique of shoemaking, while a good man is not the possessor of a technique and so moral goodness is different from the goodness of a shoemaker. According to Barnes however Aristotle would quite clearly have not accepted this conclusion: to be a good man is for Aristotle, so to speak, to be a professional man, to have an expertise at being human. Just like a lion has a typical task in life, which is to hunt, kill and consume its prey, so also the human being has a task in life. To perform this task well is to be a good man and at the same time to acquire happiness.

To show courage is therefore not - as Arendt states - to look for immortal fame. It means the preservation of the wild animal in men, not being domesticated, neither mastered by lust, nor by human rule, having the inner strength to enact what to its natural and intuitive understanding is needed. For Achilles action means to do what is needed to defend the name and unity of his family, for the civil servant it means showing independence and integrity in taking the decisions his office asks for. ${ }^{80}$

For Mill and Kant morality begins with the rational considerations about the way the freedom of the one can be in agreement with the freedom of the other. Personal freedom can be enjoyed in many different ways according to them, but this has no political or juridical relevance. For Aristotle rational considerations are empty when they do not rest on personal experience. Rational knowledge can have a truth value when it is logically consistent and demonstrable, but this is not knowledge of the world. Knowledge of the world is knowledge of individual configurations and these cannot be denoted by general concepts. ${ }^{81}$ Sure knowledge is the practical knowledge of the man in action and this knowledge is intuitive and non-conceptual. 
Although this knowledge is sure it is completely dependent on the personal interests of the practitioner. Rational contemplation has the political function to gain a more disinterested outlook by reflection on these practical experiences. As Barnes notes:

\begin{abstract}
The Aristotelian contemplator is a man who has already acquired knowledge; and what he is contemplating is precisely this knowledge already present in his mind. Contemplating is something like a review or survey of existing knowledge: the contemplator is engaged in the orderly inspection of truths which he already possesses; his task consists in bringing them forward from the recesses of his mind and arranging them fittingly in the full light of his consciousness. (...) In this way contemplation is a quasi-aesthetic appreciation of knowledge and truth. ${ }^{82}$
\end{abstract}

I have cited here Barnes in full length because I think that this description of contemplation is an excellent description of the art of Jurisprudence as it was understood before it got narrowed down to the quasi logical operation of the systematisation of authoritative rules and decisions. It is the supreme kind of knowledge as described by Plato ${ }^{83}$ It is a kind of knowledge which still is favoured by many jurists as the core of their discipline, but which they find impossible to explain to all those who understand law as the application of rules. It is a kind of pondering over the practical experiences one has acquired in particular situations, combined with the general knowledge of things one possesses, to come to a general insight in the nature of existence. Bereaved from the appetitive intelligence of action this speech-intelligence is empty, because it has no intuitive experiences to work on.

A notion of the morally good in a modern sense is impossible for Aristotle because his conception of the variability of the world is incompatible with a notion of predictable consequences of action. ${ }^{84}$ So for example when Penelope waits so many years for Odysseus, this only gets the meaning of fidelity because Odysseus returns. Would she have died while Odysseus never returned, she would have died as someone who had not been able to cope with the hard facts of life. Had she remarried and lived a happy life, while Odysseus would return after her death, she then by this fact only still would have been marked out as disloyal. Plato's State ends with the myth of Er in which the good man goes to heaven, but when he returns to life and is allowed to choose his lot for a new life, he is apt to make a stupid choice because he is not experienced. Plato assumes that such a man had probably only been able to live a life as a good man because life had been easy on him. 
As the notion of predictable outcomes of action is not accepted by Aristotle, general insights of any kind may help man to form a picture of the world in which he is placed and in terms of which action acquires a meaning. This broad and general outlook has not only a function for the understanding of one's own stand in life, but specifically for the possibility to judge others and to take decisions with a broad view of possible consequences. As we have noted above, this general outlook is primarily an attitude and not knowledge.

\section{II.5.The birth of absolute state sovereignty}

Aristotle criticizes vehemently the view on the state of Plato. It is, according to him, very important that the state - although it is in a certain sense a unity, which can be compared to a body with organs - always also can still be perceived as a partnership of individuals and families. The state is a legal bond based on proportional reciprocity, on voluntary exchange of services. For this exchange it is important that there is a difference between the elements in the state, cooperating on the basis that the one needs a service from the other. The state is thus conceived by Aristotle as an arrangement between actual groups (households/clans) with their own internal organisation of power. The free men are part of the household, such as the households are part of the state. When the state becomes more unified, the bond between the individual and his household will be loosened. This will make this individual more independent from his household, but more dependent on the state. When the unification process proceeds too far the state turns into a household and the independence of the individual will be lost. When the state becomes too much of a unity it will become an aggregation of individuals like a military force. ${ }^{85}$

The distinction between the oikos and the polis is made by Aristotle to explain that a healthy state should not turn into a unity. When Arendt maintains that the state has turned into a household, she does not indicate this structural requirement, but the fact that the human being gets too much concentrated on his bodily welfare. According to Aristotle there is nothing wrong with a concentration on bodily welfare, only perhaps as far as implied by the words "too much".

The Spanish Naturalists played an important role in the development of a new unified concept of the state with centralised absolute sovereignty. They secularized the concept of the Christian community of believers into the ideal of a State. They developed a concept of the state, ethic@- Florianópolis, v. 10, n. 2, p.223-253,Dez. 2011. 
which was no longer understood as a bundle agreements between all sorts of actual centres of powers, like it had been till then, but as created by God. They turned from an inductive conception of natural law in which people try to detect patterns in real life and catch them with words towards a deductive conception of natural law in which people conjecture ideal states of being.

The Spanish naturalists believed that once long ago there had been a "golden" society where people had lived as a unity without private property or slavery. As this society had turned bad God had created different peoples, dispersed over the world, with different languages, who make wars. ${ }^{86}$ This is what Foucault must have meant when he wrote about the rise of a new conception in which the state has an independent existence as a kind of natural object with its own nature and rationality. ${ }^{87}$ The new concept of absolute state sovereignty was developed by the Spanish Naturalists through the explicit rejection of the idea of Aristotle that group-forming between human beings is caused by the expediency which originates in natural inequality, while the equality between groups makes legal bonds possible.

After the birth of a people or a state as a natural thing it becomes possible to theorize on how states are run in the best way. There is already sovereignty, the question is if this is absolute or divided and who is the bearer of it. Is the monarch the bearer of it but only as far as he respects the given internal status quo of civil associations and arrangements? Or does the monarch have absolute sovereignty, having the power to change the laws on which these associations and arrangements rest? In that case the monarch has the Plenitudo Potestatis, the absolute sovereignty. The dilemma between both options is that the first is more democratic, while the second gives more room for social change and development. It is clear that the new rationality has forced the concept of Plenitudo Potestatis to spread. While the Dutch fought a war of eighty years with the Spanish in resistance to this concept of absolute sovereignty, they could not prevent this turn to centralism as the new rationalism forced it into this direction.

\section{II.6. The birth of a modern concept of positive law}

Hans Kelsen ${ }^{88}$ maintained that in the theory of government of Aristotle there is a distinctive peculiarity. Aristotle starts, according to him, from two different standpoints, using ethic@- Florianópolis, v. 10, n. 2, p. 223 -253, Dez. 2011. 
two methods in answering the question as to the best form of governments, each exclusive of the other: one pointing at hereditary monarchy, the other at the mixed form of democracy and oligarchy. He explained this duality by the effort of Aristotle to present on the one hand - being in the service of King Philip of Macedonia - hereditary monarchy as the highest ideal of constitution, while on the other he desired to assign to democracy in a moderate form a place which fitted into the tradition of the Greek cities. In my opinion Kelsen overlooks here the fact that Aristotle clearly understands the antinomy between a balance of powers (administrative order) and the realization of justice (juridical system). Aristotle rejects "legalism" which understand jurisdiction as nothing else than the application of rules and which thereby tries to conciliate the antinomy between both systems of order. ${ }^{89}$ As Aristotle phrases the antinomy:

He therefore that recommends that the law shall govern seems to recommend that God and reason alone shall govern, but he that would have man govern adds a wild animal also; for appetite is like a wild animal, and also passion warps the rule even of the best men. Therefore the law is wisdom without desire. ${ }^{90}$

When Aristotle treats the possibility that one would choose to let the best man decide, the link with Homo Sacer becomes clear:

But if there is any one man so greatly distinguished in outstanding virtue, or more than
one, but not enough to be able to make up a complete state (...) it is no longer proper to
count these exceptional men a part of the state; for they will be treated unjustly if
deemed worthy of equal status (...) Hence it is clear that legislation also must
necessarily be concerned with persons who are equal in birth and in ability, but there can
be no law dealing with such men as those described, for they are themselves a law;
indeed a man would be ridiculous if he tried to legislate for them $(\ldots)$ This is why
democratically governed states institute the system of ostracism, because a reason of this
nature; for these are the states considered to pursue equality most of all things, so that
they used to ostracize men thought to be outstandingly powerful on account of wealth or
popularity or some other form of political strength, and used to banish them out of the
city for fixed periods of time.

This consideration about the way democracy is inimical to great men together with his considerations about the need for and danger of jurisdiction leads Aristotle in my opinion to his choice for the mixed nature of government.

Rousseau states that the people have absolute sovereignty but only as an aggregation of individuals of whom each speaks for himself. Only when all the associations and arrangements of the status quo are left behind there can be a rational procedure which guarantees that when every 
individual uses his intellect the result will be a general will. ${ }^{92}$ Rousseau imposes here individualisation explicitly as a totalizing procedure. ${ }^{93}$

Rousseau thus rejects the Aristotelian warning against unity in the state. To act the aggregate of individuals needs an executing body. This executing body - the Monarch - can be democratic, aristocratic or monarchical, depending on the circumstances. There is a sharp distinction between laws willed by the sovereign body - which express the true general interest of all - and general dispositions made by the Monarch - which necessarily are contaminated by all sorts of concrete specific interests. As it is difficult to discern the true general interest of all Rousseau thinks of the legislator ${ }^{94}$ in the Ancient way - like Solon or Lycurgus - as a stranger who is not part of the political community and who tries to find out which laws are accepted throughout the ages in different countries and thus trustworthy, and next to this which laws seem suitable for this community given the circumstances. Because of his view on legislation Rousseau's teachings were impractical. ${ }^{95}$

What was needed in respect of the modern rationality was the formation of a concrete centralised will of the people, in other words a fusion between Rousseau's democratic legislator and Rousseau's monarch: a representative government (which he explicitly rejected). Only within the context of the governmental representation of the general interest of all, legislation could be developed as the dynamic force which would change the surface of the earth. ${ }^{96}$ This fusion creates legalism: the positivist conception of law. I will not work out here how this legalism did develop and only indicate that it was developed from the end of the eighteenth century on by the figure of stare decisis in England, by the idea of systematization in Germany, and by the idea of an eminent legislator (Napoleon/Portalis) in France.

In the positivist conception of law, civil obedience does not only mean "not getting involved in treason", but "following the commands of the state from inner will as if they are the commands of God, Reason or Nature". Law by this feature can become an instrument of discipline and change. Law does not refer primarily any longer to a theoretical understanding of human affairs arising from the careful analysis of court decisions in actual quarrels between citizens or associations of citizens: the civil law. The new concept of law refers primarily to public regulations, made by the state-officials, informed by scientists. 
To understand why in contemporary societies the exception becomes the rule it is important to remember what the modern scientific method involves: it constructs an understanding of the world in which the variation has been overcome from the perspective of a certain question. This presupposes the perspective of a problem and the characteristics in which one is interested accordingly. Change the perspective and one has to undo the earlier harmonization to reconstruct a new one. 


\section{Notes}

\footnotetext{
${ }^{1}$ Revised version of a paper presented at the special workshop on Aristotle and the Philosophy of Law at the IVR conference at Beijing in 2009.

${ }^{2}$ E.A.Huppes-Cluysenaer@uva.nl.
}

${ }^{3}$ More on these misconceptions in E.A. Huppes-Cluysenaer, "The Individual Realism of Aristotle". In: Revista da Faculdade de Direito de Conselheiro Lafaiete, Nova Fase, v. 3, ISSN 1679-8139, pp. 65-83. Available at SSRN: http://ssrn.com/abstract=1386937 and in the second part of this article.

${ }^{4}$ Giorgio Agamben, Homo Sacer, Sovereign Power and Bare Life (HS, 1995), Introduction 4/5. Page numbers refer to the English text which is available at the internet: thttp://korotonomedya2.googlepages.com/GiorgioAgambenHOMOSACERSovereignPow.pdf.

${ }^{5}$ Aristotle, Politics, 1253a, 10-18, Agamben, H.S., Introduction, 8. Note the fact that Aristotle does not restrict this remark only to the city-state, but includes the household.

${ }^{6}$ Hannah Arendt, The Human Condition (HC, 1958), The University of Chicago Press, Chicago 1998, 97.

${ }^{7} \mathrm{HC}, 176$.

${ }^{8} \mathrm{HC}, 181$.

${ }^{9} \mathrm{HC}, 198$.

${ }^{10} \mathrm{HC}, 5$.

${ }^{11}$ HC, 24. Arendt cites W. Jaeger's Paideia (1945) on this. My criticism of Arendt will be in the same vein as the criticisms of G.H. Sabine (1937), History of Political Theory, Holt, Rinehart and Winston, New York, 1961; J.A. Swanson, The Public and the Private in Aristotle's Political Philosophy, Cornell University Press, Ithaca, 1992; Arlene Saxonhouse in Athenian Democracy: Modern Mythmakers and Ancient Theorists, University of Notre Dame Press, Notre Dame and London, 1996; and G. Drosterij, Politics as Jurisdiction, a New Understanding of Public and Private in Political Theory, Doctoral Thesis, Tilburg University 2008. Downloadable at: http://gerarddrosterijnl.files.wordpress.com/2008/02/drosterij_binnenwerk.pdf

${ }^{12} \mathrm{HC}, 145$. As will be explained in greater detail, this is a mistaken interpretation of Aristotle. "Now surely as in action, so in nature; and as in nature, so it is in each action, if nothing interferes. Now action is for the sake of an end; therefore the nature of things also is so. Thus if a house e.g. had been a thing made by nature, it would have been made in the same way as it is now by art; and if things made by nature were made not only by nature but also by art, they would come to be in the same way as nature." Physics, Book II, chapter 8.

${ }^{13} \mathrm{HC}$, 95: "The materialization they have to undergo in order to remain in the world at all is paid for in that always the 'dead letter' replaces something which grew out of and for a fleeting moment indeed existed as 'the living spirit'. They must pay this price because they themselves are of an entirely unworldly nature and therefore need the help of an activity of an altogether different nature; they depend for their reality and materialization upon the same workmanship that builds the other things in the human artifice."

${ }^{14} \mathrm{HC}, 28$.

${ }^{15}$ HC, 193-194: "Only a man who does not survive his one supreme act remains the indisputable master of his identity and possible greatness, because he withdraws into death from the possible consequences and continuation of what he began (...) Even Achilles, it is true, remains dependent upon a storyteller, poet or historian, without whom everything he did remains futile; but he is the only 'hero', and therefore the hero par excellence, who delivers in the

ethic@-Florianópolis, v. 10, n. 2, p. 223 -253, Dez. 2011. 
narrator's hands the full significance of his deed (...) As such it became the prototype of action for Greek antiquity and influenced, in the form of the so-called agonal spirit, the passionate drive to show one's self in measuring up against others that underlies the concept of politics prevalent in the city-states."

${ }^{16} \mathrm{HC}$, 194: "In their opinion, the lawmaker was like the builder of the city wall, someone who had to do and finish his work before political activity could begin."

${ }^{17} \mathrm{HC}, 222:$ "Escape from the frailty of human affairs into the solidity of quiet and order has in fact so much to recommend it that the greater part of political philosophy since Plato could easily be interpreted as various attempts to find theoretical foundations and practical ways for an escape from politics altogether. The hallmark of all such escapes is the concept of rule, that is, the notion that men can lawfully and politically live together only when some are entitled to command and the others forced to obey."

${ }^{18} \mathrm{HC}$, 40: "But this nobody, the assumed one interest of society as a whole in economics as well as the assumed one opinion of polite society in the salon, does not cease to rule for having lost its personality. As we know from the most social form of government, that is, from bureaucracy (the last stage of government in the nation state just as one-man rule in benevolent despotism and absolutism was its first), the rule by nobody is not necessarily no-rule; it may indeed, under certain circumstances, even turn out to be one of its cruelest and most tyrannical versions."

${ }^{19} \mathrm{HC}, 40$.

${ }^{20} \mathrm{HC}, 63$, Arendt situates the degeneration of politics from action into work on the one hand with Plato and Aristotle, maintaining that already in Rome the idea was held that politics is about legislation, while on the other hand she states that the idea that politics is about making a catalogue of prohibitions is typically modern and finds its greatest expression with Kant.

${ }^{21}$ Michel Foucault, "The Political Technology of Individuals" (PTI), in: Technologies of the Self, a seminar with Michel Foucault, eds. Luther H. Martin, Huck Gutman, Patrick H. Hutton, Tavistock Publications, London,1988, 145-163.

${ }^{22}$ PTI, 146/147, 1779 System einer vollstaendigen Medicinische Polizei by J.P. Frank.

${ }^{23}$ PTI, 151.

${ }^{24}$ PTI, 152.

${ }^{25}$ Foucault, PTI, 147.

${ }^{26}$ HS, Introduction, 5, Part three, par. 1, 76.

${ }^{27}$ HS, Part one, par. 1, 12-21.

${ }^{28}$ HS, between others Part two, par. 3: 54-57.

${ }^{29}$ HS, Part two, par. 5, 68.

${ }^{30} \mathrm{HS}$, Introduction, 8: "Politics therefore appears as the truly fundamental structure of Western metaphysics insofar as it occupies the threshold on which the relation between the living being and the logos is realized. In the 'politicization' of bare life - the metaphysical task par excellence - the humanity of living man is decided. In assuming this task, modernity does nothing other than declare its own faithfulness to the essential structure of the metaphysical tradition."

\footnotetext{
${ }^{31}$ Agamben, HS, Introduction, 8-9.

${ }^{32} \mathrm{HS}$, Introduction, 7-9.

ethic@-Florianópolis, v. 10, n. 2, p.223-253, Dez. 2011.
} 


\begin{abstract}
${ }^{33} \mathrm{HS}$, Introduction, 9: "If anything characterizes modern democracy as opposed to classical democracy, then, it is that modern democracy presents itself from the beginning as a vindication and liberation of zoe, and that it is constantly trying to transform its own bare life into a way of life and to find, so to speak, the bios of zoe."
\end{abstract}

${ }^{34}$ Emile Durkheim, The Elementary Forms of the Religious Life (EF), George Allen \& Unwin LTD, Book II, Chapter VI, par. II and III, 191-199.

${ }^{35}$ EF, Book II, chapter VII, par. IV, 229-236.

${ }^{36}$ See for panopticum especially Foucault's Discipline and Punishment.

${ }^{37}$ Emile Durkheim, The division of labor in society (DLS), The Free Press, New Yok, 1964 (1893), Book I, chapter II, par. I, 80 .

${ }^{38}$ HS, Part II, par. 2, 51.

${ }^{39}$ Emile Durkheim, “Deux lois de l'évolution pénale”, in: L'Année sociologique, 4 e année, 1899/1900, 65-95.

${ }^{40}$ HS, Part three, par.1, 77-78: "If there is a line in every modern state marking the point at which the decision on life becomes a decision on death, and biopolitics can turn into thanatopolitics, this line no longer appears today as a stable border dividing two clearly distinct zones. This line is now in motion and gradually moving into areas other than that of political life, areas in which the sovereign is entering into an ever more intimate symbiosis not only with the jurist but also with the doctor, the scientist, the expert, and the priest. In the pages that follow, we shall try to show that certain events that are fundamental for the political history of modernity (such as the declaration of rights), as well as others that seem instead to represent an incomprehensible intrusion of biologico-scientific principles into the political order (such as National Socialist eugenics and its elimination of 'life that is unworthy of being lived', or the contemporary debate on the normative determination of death criteria) acquire their true sense only if they are brought back to the common biopolitical (or thanatopolitical) context to which they belong. From this perspective, the camp - as the pure, absolute, and impassable biopolitical space (insofar as it is founded solely on the state of exception) - will appear as the hidden paradigm of the political space of modernity, whose metamorphoses and disguises we will have to learn to recognize."

${ }^{41}$ I (*Kant) do not here follow with exactness the history of the experimental method, of which, indeed, the first steps are involved in some obscurity.

${ }^{42}$ Translation used: www.malaspina.com/etext/pure02.htm.

${ }^{43}$ NE, book VI, 1141a19-1141b8.

${ }^{44}$ PTI, 151.

${ }^{45}$ Politics, Book I, i, 1252b 20-1253a10: "Hence every city-state exists by nature (...) the city-state is a natural growth"; Durkheim, DLS, Book I, chapter I, par. 3.

${ }^{46}$ Politics, Book I, i, 1252a 20-1252b 30; Durkheim on mechanical solidarity, DLS, Book I, chapter II.

${ }^{47}$ Politics, Book I, 1 1252a, 1-15; Durkheim, DLS, Book II, chapter II, par. 3.

${ }^{48}$ Politics, Book I, ii, 1255b15-35.

${ }^{49}$ Politics, Book I, i, 1252b5-10 and Book I, iv, 1259a 35-1259b 20.

${ }^{50}$ See Durkheim DLS, Book I, chapters II and III.

${ }^{51}$ Politics, Book II, i, 1261a30, Book III, iv, 1278b15; Durkheim DLS, Book I, chapter III.

ethic@-Florianópolis, v. 10, n.2,p.223-253,Dez. 2011. 
${ }^{52}$ Politics, Book I,i, 1253a 1-35; Durkheim, DLS, Book I, chapter III.

${ }^{53}$ Politics, Book II, v, 1269a 20-30; Durkheim DLS, Book I, chapter IV, par. 2, 146.

${ }^{54}$ Barnes underlines in the Introduction of the Penguin edition of the Nicomachean Ethics that Aristotle adopts an extreme position in this respect, comparable to the existentialists.

${ }^{55}$ See idem Barnes for the notion of Akribeia.

${ }^{56}$ Metaphysics, X, iii,1054b-1059a; Physics, I,v,188b; Physics,II,ii, 194b.

${ }^{57}$ NE, Book I, 1102b28-1103a10, also Book VI, 1141a19-b8; Physics II, viii, 199a.

${ }^{58} \mathrm{NE}$, Book VI, 1138b18-34.

${ }^{59} \mathrm{NE}$, Book VI, $1140 \mathrm{~b} 33$.

${ }^{60}$ Durkheim, DLS, Book I, chapter III, par. 4, 130.

${ }^{61}$ Durkheim idem. See also H. Spencer, Structure, Function and Evolution, Charles Scribner's Sons, New York, 1971, p. 37. (From The Study of Sociology, 1889)

${ }^{62}$ Durkheim, DLS,Book I, chapter III, par. 4, 131.

${ }^{63}$ Durkheim, Book I, chapter I, par. 2, 56.

${ }^{64}$ Idem, 61. See also the reference to Comte on pages 62 and 63.

${ }^{65}$ Politics, Book III, v, 1280b 1-1281a 5.

${ }^{66}$ See on this Book I of Politics in general.

${ }^{67}$ G. Drosterij, o.c. (see footnote 10) introduces the term Jurisdiction as a sensitizing concept.

${ }^{68}$ J.A. Van Ruler, The Crisis of Causality, Voetius and Descartes on God, Nature and Change, Doctoral Thesis, University of Groningen, 1995, 31.

${ }^{69}$ J.A. Van Ruler, o.c., 38.

${ }^{70}$ Idem, 54,55 .

${ }^{71}$ Idem, 59.

${ }^{72}$ Addition of Regius to an instruction of Descartes, cited by J.A. Van Ruler, o.c., 39.

${ }^{73}$ Idem, 113-115.

${ }^{74}$ Idem, 118-120.

${ }^{75}$ Descartes in Le Monde ou Traité de la Lumière, cited in Van Ruler, 120.

${ }^{76}$ Van Ruler, o.c., 141-143.

${ }^{77}$ Idem, 231-232.

ethic@- Florianópolis, v. 10, n. 2, p. 223 -253, Dez. 2011. 


\begin{abstract}
${ }^{78}$ Van Ruler o.c., 129-131. See also 133/134 where it is explained that: "For Descartes, the movement of air is the [physical, efficient cause of the mental effect of hearing a sound (...) According to Schoock (belonging to the camp of Voetius HC) for instance, the movement of a bell is not the efficient cause of its ringing. The movement is itself part of the ringing. It is the one who rings the bell, 'the sacristan', who is the efficient cause. (...) Descartes exclusively introduces images of particles of matter influencing other particles of matter in his theory concerning the formation of ice, whilst Schoock regards cold as a real quality having causative powers. "
\end{abstract}

${ }^{79}$ In the Introduction of the Penguin edition of the Nicomachean Ethics. For a vehement rejection of the idea of rational passions see also Hume, A treatise of Human Nature, II, part 3, sect iii, Penguin Classics 1984, 463.

${ }^{80}$ See below footnote 89 .

${ }^{81}$ As G. Drosterij words it (o.c., 136-137): "We can say, recapitulating, that with his rationalist injunction 'dare to know' (sapere aude) Kant challenged not only Luther's inner dictum 'bij faith alone'(sola fide) but also Rousseau's interpretation of existential sentimentality. With Kant, the modern experience of subjectivity creates a duty to use reason, which compensates for the difficult Protestant paradox of the privatization of conscience and the predestination of fate. The modern individual is endowed with a potential public identity prior to all his private roles: he or she is member of the human society. All subjects are equal by merit of their membership of the association of humankind. The prominence of this humanism - which, ironically, resides in subjectivity - illustrates the process of religious secularization: the existential sphere loses its independent function as a spiritual shelter, a place of sentimental solitude, and turns into a breeding ground for human rationality. This secularization process is embodied by deliberation and will formation with the object of attaining civil harmony. The stage where this takes place is the public sphere".

${ }^{82}$ Idem, 38.

${ }^{83}$ In Symposium, 209.

${ }^{84}$ As is rightly observed also by Arendt, HC, 192.

${ }^{85}$ Politics, Book I, i, 1253b1-15; Book II, i, 1261a20-1261b 16; Book III, 128030-1281a; NE, Book V, 1232 b33.

${ }^{86}$ Hobbes, Leviathan, part 1, chap. iv: "The first author of Speech was God himself, that instructed Adam how to name such creatures as he presented to his sight (...) But all this language gotten, and augmented by Adam and his posterity, was again lost at the tower of Babel, when by the hand of God, every man was stricken for his rebellion, with an oblivion of his former language. And being hereby forced to disperse themselves into several parts of the world, it must needs be, that the diversity of Tongues that now is, proceeded by degrees from them, in such manner, as need (the mother of all inventions) taught them; and in tract of time grew everywhere more copious". Specific about the Spanish naturalists G.P van Nifterik, "Fernando Vázquez on the Prince and the Law". In: Jurisprudenz, Politische Theorie und Politische Theologie, Beitrage des Herborner Symposions zum 400. Jahrestag der Politica, Duncker\&Humblot, Berlin, 2004.

${ }^{87}$ PTI, 151.

${ }^{88}$ H. Kelsen (1937-1938), “Aristotle and Hellenic-Macedonian Policy”. In: Articles on Aristotle, 2 Ethics and Politics, eds. Jonathan Barnes, Malcolm Schofield, Richard Sorabii, Duckworth, London, 1977, 186.

${ }^{89}$ Politics, Book III, x, 1286a1-35: "Those of the opinion that it is advantageous to be governed by a king think that laws enunciate only general principles but do not give directions for dealing with circumstances as they arise; so that in an art of any kind it is foolish to govern procedure by written rules (...) it is clear therefore that government according to written rules, that is laws, is not the best, for the same reason. At the same time, however, rulers ought to be in possession of the general principle before mentioned as well. And a thing that does not contain the emotional element is generally superior to a thing in which it is innate; now the law does not possess this factor, but every human soul necessarily has it. But perhaps someone might say that in compensation for this a single ruler will decide better about particular cases. Therefore it is clear that on the one hand the ruler must necessarily be a legislator, and

ethic@-Florianópolis, v. 10, n. 2, p. 223 -253, Dez. 2011. 
that there must be laws laid down, although these must not be sovereign where they go astray - admittedly in all other cases they ought to be sovereign; but on the other hand in matters which it is impossible for the law either to decide at all or to decide well, ought the one best man to govern or all the citizens?"

${ }^{90}$ Politics, Book III, xi, 1287a 25-40.

${ }^{91}$ Politics, Book III,vii, 1283 b - 1284a 15.

92 On Social Contract, book II, 3: "There is often a great difference between the will of all and the general will; the latter looks only to the common interest; the former looks to the private interest and is only a sum of particular wills, but take away from these same wills the pluses and the minuses that cancel each other out, and the general will remains as the sum of the differences (...) It is important, therefore, in order to have a clear enunciation of the general will, that there be no partial association in the state and that each citizen speak only for himself'. See also Kant on the Weltbürgerliche Gemeinschaft.

${ }^{93}$ It is very instructive in this respect to read how all the textbooks on social science urge against parochialism.

${ }^{94}$ Rousseau op. cit. Book II, 7.

${ }^{95}$ Beccaria or Montesquieu, authors often referred to in the context of a defence of legalism, cannot have had in mind a positivist concept of law.

${ }^{96}$ C.S. Peirce, Collected Papers of Charles Sanders Peirce, eds. Ch. Harthorne and P. Weiss, Harvard University Press, Cambridge, Mass, 1960, part I, Principles of Philosophy, p. 95. 